Institute of $\mathbf{F}_{\text {ood and }} \mathbf{A}_{\text {gricultural }} \mathbf{S}_{\text {ciences }}$

\title{
Agricultural Producer Attitudes Toward Agri-Tourism in Miami-Dade County, Florida ${ }^{1}$
}

Thomas J. Stevens, Robert L. Degner, and Kimberly L. Morgan²

\section{Introduction}

This report presents the findings of a survey on the willingness of agricultural producers in Miami-Dade County, Florida to participate in a cooperative agri-tourism program. It evaluates and discusses the benefits and risks that producers perceived about diversifying their enterprises to include such activities.

\section{Current Situation}

Miami-Dade County's desirable location and climate, in combination with its abundant resort amenities, attract millions of domestic and foreign visitors to the area annually. In 2001, there were over 10.5 million overnight visitors to the area, half of which were from foreign countries (Greater Miami Convention and Visitors Bureau, 2002). The County is also unique among other major U.S. tourist destinations in that it hosts a large, dynamic agricultural industry that produces a wide variety of tropical fruits and vegetables.

Eco-tourism and agri-tourism are rapidly growing industries in some areas of the United States. In many circumstances, with reasonable accommodations, entrepreneurial growers can increase consumer awareness, promote their agricultural products, and even generate direct sales in conjunction with their commercial operations. In addition to fostering better public relations, these activities can also increase profitability.

Despite the apparent opportunities and benefits for agriculture to exploit its proximity to the area's tourism, only a limited number of organizations and businesses provide agri-tourism type opportunities in the Miami-Dade area. Some of the participants include Burr's Berry Farm; Fairchild Tropical Gardens (which sponsors the International Mango Festival); Knaus Berry Farms; the Miami-Dade County Fair and Exposition; Orchid Jungle; the Redland Fruit and Spice Park (which sponsors the Redland Farm and Garden Show and the Redland International Orchid Festival); Robert's Is Here fruit stand; and the Southern Florida Tropical Growers, Inc. (which sponsors the Tropical Agricultural Fiesta). Among these organizations there is little coordination or information sharing. While the Miami-Dade County Agricultural Extension Service is an important educational resource for agriculture and related issues in the area, it is not organized to promote commercial agri-tourism.

1. This is EDIS document FE359, a publication of the Department of Food and Resource Economics, Florida Cooperative Extension Service, Institute of Food and Agricultural Sciences, University of Florida, Gainesville, FL. Published October 2002. Please visit the EDIS website at http://edis.ifas.ufl.edu.

2. Thomas J. Stevens, Post-Doctoral Associate; Robert L. Degner, Professor; and Kimberly L. Morgan, Coordinator of Economic Analysis; Department of Food and Resource Economics, Florida Cooperative Extension Service, Institute of Food and Agricultural Sciences, University of Florida, Gainesville, FL.

The Institute of Food and Agricultural Sciences is an equal opportunity/affirmative action employer authorized to provide research, educational information and other services only to individuals and institutions that function without regard to race, color, sex, age, handicap, or national origin. For information on obtaining other extension publications, contact your county Cooperative Extension Service office. Florida Cooperative Extension Service/Institute of Food and Agricultural Sciences/University of Florida/Christine Taylor Waddill, Dean. 


\section{Research Objective}

An opportunity to explore producer attitudes regarding agri-tourism came about when a future land-use study of Miami-Dade County was commissioned by the Florida Department of Agriculture and Consumer Services to the University of Florida in 2000 (Degner et al., 2002). Part of this study involved a comprehensive survey effort to elicit opinions and ideas from the agricultural community regarding infrastructure and policy issues that impacted area farms and agribusinesses. One section of the survey was devoted to polling respondents about the likelihood of their participation in a cooperative agri-tourism program and the benefits and risks they perceived from doing so. Over 2,800 written questionnaires were mailed to private-sector individuals and organizations in the County during the winter of 2001. A total of 333 responses were received.

\section{Survey Findings}

Survey participants were asked whether they were likely to participate in a cooperative agri-tourism program that would bring visitors to their operations for tours and retail sales. A semantic-differential response format was used to classify their response with three choices: "very likely", "somewhat likely", and "not at all likely". Producers were then asked, in an open-ended format, what benefits and risks, if any, an agri-tourism program would pose for their operation. The responses to each of these questions are discussed below.

\section{Likelihood of Participation}

Producer semantic-differential responses to their likely participation in an agri-tourism program are presented by operation type in Table 1 . From left to right, the columns contain the number of completed survey questionnaires, the number of agri-tourism participant responses, and the percent selecting one of the three responses for each operation type.

Of the 333 survey questionnaires returned, 274 respondents completed the question on the likelihood of participation in agri-tourism. With the exception of aquaculture, 50 percent or more of the respondents in each of the operation types indicated that they were unlikely to participate in a cooperative agri-tourism program. Vegetable producers had the lowest response rate to this issue (32 out of 47 respondents, or 68 percent) and were also the least interested in agri-tourism, with 65.6 percent indicating that they were "not at all likely" to participate in such a program. After vegetable producers, nursery operations were the next least likely to embrace agri-tourism, with 57.3 percent indicating that they were "not at all likely" to participate. Fruit and aquaculture operations were the most favorably disposed toward agri-tourism, with 30.7 and 27.3 percent, respectively, indicating they would "very likely" participate in such a program.

A chi-square test was performed to determine whether semantic-differential responses between the four types of operations were statistically different. This test, with four degrees of freedom, had a probability value of 0.126 , which means there would be a 12.6 percent chance of being wrong if it were concluded that responses were different between operation types. This indicates that while there are some differences in responses among fruit, vegetable, and nursery operations (aquaculture responses were not included in the test because of the small number of respondents of this type), these differences were not great enough to be considered statistically significant.

Data on the size of respondents' operations were also requested in the survey. It seems plausible that smaller operations may be more interested in diversifying their operations and taking advantage of possible direct-retail-sales opportunities associated with agri-tourism, while larger operations would seem more likely to structure their marketing efforts toward high-volume wholesale channels. Larger agricultural operations may also perceive a greater liability risk from agri-tourism activities (deeper pockets) than relatively smaller operations. To evaluate whether operation size influenced producers' willingness to engage in agri-tourism, survey respondents were classified as either "small" or "large" based on the number of acres in their operations. Allowances were made for the type of operation in this classification. Vegetable operations with 100 acres or more were considered large; 
otherwise they were classified as small. For fruit operations, the breakpoint between small and large was set at 20 acres, and for nursery operations, it was set at 10 acres. In Miami-Dade County, vegetable operations typically use land more extensively than fruit, nursery, or aquaculture enterprises.

The response numbers and percentages for small and large operations of each operation type and for all types combined are presented in Table 2 . Information on acreage was provided by 239 of the 274 respondents who completed the agri-tourism participation question. More than twice the proportion of all types of small operations (25.8 percent) were "very likely" to participate in a cooperative agri-tourism program compared to all types of large operations (11.8 percent). Within specific types of operations, perhaps the greatest difference occurred between small and large nurseries. Over 21 percent of small nursery operations indicated that they were "very likely" to participate in agri-tourism program compared to less than six percent of large nurseries. Similar but less dramatic differences are seen between small and large fruit growers, but equal proportions of small and large vegetable growers were "not at all likely" to participate in an agri-tourism program.

Chi-square tests were again performed to see if these differences were statistically significant. None of the tests for response differences between small and large operations of a particular type were found to be statistically significant, although the probability value of the test on small and large nursery operations (0.11) was very close to the 10 -percent threshold. When the chi-square test was performed for response differences between all types of small and large operations, however, it was found to be highly significant. With two degrees of freedom, the chi-square value was 6.79 , with a probability value of 0.034 . Thus a statistically significant difference in the acceptability of agri-tourism is found to occur between small and large operations in the County.

\section{Perceived Benefits and Risks}

Responses to the open-ended requests for perceived benefits and risks of agri-tourism were reviewed and categorized by the general type of characteristic cited. The results of this categorization are shown in Tables 3 and 4. Because of the greater variety of responses, the results from this part of the survey were not broken out by operation type.

Overall, more risks were perceived than benefits. Six percent fewer participants provided responses to agri-tourism's benefits compared to its risks, and 24 more risks were listed by respondents than benefits.

The types of responses in Tables 3 and 4 are ranked in order of frequency cited. Almost 49 percent of the producers indicated that there were no or few benefits to agri-tourism (Table 3 ). In many cases, this was just a complementary affirmation of each participant's responses to agri-tourism's risks. Increased consumer awareness (familiarity with the product or industry) was the most frequently (34.6 percent) cited benefit of agri-tourism. Twenty-two percent of respondents indicated that agri-tourism could produce increased sales or profits for their organizations. There were a variety of other benefits cited, but the vast majority fell into the first two categories.

There was a greater variety of perceived risks that discouraged producers from participating in agri-tourism (Table 4). Many of these hinge on the very nature of agricultural production itself. The most frequently cited risk was liability, which was listed by over 42 percent of those responding to the survey. Clearly, accidents and exposure to pesticides and powerful industrial equipment pose real and present risks to employees and visitors alike in many agricultural production settings. To reduce or prevent accidents would require significant investments in safety equipment and labor for some types of agricultural operations. Indeed, the second most frequented listed risk for agri-tourism was added costs or reduced productivity (costs for additional labor and amenities necessary to accommodate visitors). Included within this category of responses were those indicating that agri-tourism would interfere with regular production activities on the work site.

A significant minority of respondents saw no particular risks to engaging in agri-tourism activities. Over 28 percent of producers responding to the question on perceived risks indicated that there were none. Of course, this is a reflection of those 
operations that listed numerous benefits to agri-tourism in the other half of the question.

Other issues that tend to discourage producers from engaging in agri-tourism activities included phytosanitary concerns and seasonality of production and harvesting activities. Many producers believe that allowing large numbers of people to access and tour their operations would significantly increase the potential for exposing crops or groves to damaging insects and diseases. The recent devastation to the area's lime industry from citrus canker is still fresh in the minds of many producers.

Other producers expressed concerns about the seasonality of their activities. Unlike some of the notable agri-tourism industries (such as the Napa Valley wine country in California or the Vermont maple syrup industry), agricultural products grown in Miami-Dade County are seasonal and highly perishable. Consequently there are months during the year when there are no crops in the fields or mature fruit in groves to purchase or harvest. There are also certain phases of the production process where it would be very inconvenient or dangerous for tourists to be present on the farm.

\section{Summary and Recommendations}

Although Miami-Dade County would appear to have great potential for agri-tourism, currently only a limited number of organizations or businesses in the area are engaged in providing these services. A survey of agricultural producers in the area found that many have serious concerns about the feasibility of agri-tourism for their operations. Most of these concerns were related to the nature of the agricultural production practices commonly used in the area. The widespread use of chemicals and powerful mechanical equipment makes it problematic to bring untrained visitors or tourists onto many farm-work environments. Phytosanitary issues were also a major concern of area producers. Growers feared that bringing tourists onto their farms would increase the exposure of their crops and groves to potentially destructive pests and diseases. Survey respondents also pointed out that agriculture in Miami-Dade County is highly seasonal. Consequently, there are months during the year when there are few activities or products available for tourists to purchase or experience. In comparing survey responses between small and large operations, it was found that small operations were significantly more inclined to participate in a cooperative agri-tourism program than were large operations.

Currently, there is little in the way of public programs or coordinating organizations to promote the demand or supply of agri-tourism opportunities in Miami-Dade County. The formation of a coalition of enterprises that are interested and willing to participate in coordinated efforts to provide agri-tourism experiences to area visitors year-round is recommended. An advisory agri-tourism work-group or agri-tourism coordinator could be established by Florida or the County to help provide information and logistical support for enterprises wishing to explore this opportunity. This would help ensure that year-round tourism opportunities are available. An effective and dynamic agri-tourism program could significantly enhance agricultural sales in the area, particularly for small operations. Such a program would also create additional jobs in the County to provide these tour services. With over 10 million visitors already coming to the area each year, a \$20 sale to just five percent of these visitors would generate more than $\$ 10$ million in new revenues to the agriculture industry annually.

\section{References}

Degner, Robert L., et al. 2002. Miami-Dade County agricultural land retention study: Final report (Appendix D). Industry Report No. 2, Florida Agricultural Market Research Center, Institute of Food and Agricultural Sciences, University of Florida (October).

http://www.agmarketing.ifas.ufl.edu/agland.html.

Greater Miami Convention and Visitors Bureau. 2001. Greater Miami overnight visitors (January-December). http://www.gmcvb.com. 
Table 1. Likelihood of Miami-Dade County agricultural producers participating in agri-tourism.

\begin{tabular}{|lccccc|}
\hline \hline Type of Operation & $\begin{array}{c}\text { Completed } \\
\text { Surveys }\end{array}$ & $\begin{array}{c}\text { Agri-tourism } \\
\text { Responses }\end{array}$ & $\begin{array}{c}\text { Participation } \\
\text { "Very Likely" }\end{array}$ & $\begin{array}{c}\text { Participation } \\
\text { "Somewhat } \\
\text { Likely" }\end{array}$ & $\begin{array}{c}\text { Participation } \\
\text { "Not at All } \\
\text { Likely" }\end{array}$ \\
\hline Fruit & number & number & percent & percent & percent \\
Vegetables & 125 & 114 & 30.7 & 19.3 & 50.0 \\
Nursery & 47 & 32 & 12.5 & 21.9 & 65.6 \\
Aquaculture & 150 & 117 & 18.8 & 23.9 & 57.3 \\
Totals (Weighted & 11 & 11 & 27.3 & 27.3 & 45.5 \\
Average Percentages) & 333 & 274 & 23.4 & 21.9 & 54.7 \\
\hline \hline
\end{tabular}

Table 2. Comparison of likelihood of participation between small and large operations in Miami-Dade County, FL.

\begin{tabular}{|c|c|c|c|c|c|c|c|}
\hline \multirow[t]{2}{*}{ Response } & \multicolumn{2}{|c|}{$\begin{array}{l}\text { Participation } \\
\text { "Very Likely" }\end{array}$} & \multicolumn{2}{|c|}{$\begin{array}{c}\text { Participation } \\
\text { "Somewhat Likely" }\end{array}$} & \multicolumn{2}{|c|}{$\begin{array}{l}\text { Participation } \\
\text { "Not at All Likely" }\end{array}$} & \multirow{2}{*}{$\begin{array}{c}\text { Total } \\
\text { Number }\end{array}$} \\
\hline & Number & Percent & Number & Percent & Number & Percent & \\
\hline Small Fruit & 26 & $32.1 \%$ & 17 & $21.0 \%$ & 38 & $46.9 \%$ & 81 \\
\hline Small Vegetable & 1 & $9.1 \%$ & 3 & $27.3 \%$ & 7 & $63.6 \%$ & 11 \\
\hline Small Nursery & 15 & $21.1 \%$ & 18 & $25.4 \%$ & 38 & $53.5 \%$ & 71 \\
\hline Total Small Operations & 42 & $25.8 \%$ & 38 & $23.3 \%$ & 83 & $50.9 \%$ & 163 \\
\hline Large Fruit & 7 & $22.6 \%$ & 5 & $16.1 \%$ & 19 & $61.3 \%$ & 31 \\
\hline Large Vegetable & 0 & $0.0 \%$ & 4 & $36.4 \%$ & 7 & $63.6 \%$ & 11 \\
\hline Large Nursery & 2 & $5.9 \%$ & 8 & $23.5 \%$ & 24 & $70.6 \%$ & 34 \\
\hline Total Large Operations & 9 & $11.8 \%$ & 17 & $22.4 \%$ & 50 & $65.8 \%$ & 76 \\
\hline
\end{tabular}


Table 3. Perceived benefits of agri-tourism participation, by producers, Miami-Dade County, FL (2001).

\begin{tabular}{|lcc|}
\hline \hline Type of Perceived Benefit & Number & Percent $^{\mathrm{a}}$ \\
\hline No or Few Benefits & 93 & $48.7 \%$ \\
Increased Consumer Awareness & 66 & $34.6 \%$ \\
Increased Sales or Profits & 42 & $22.0 \%$ \\
Other Benefits & 11 & $5.8 \%$ \\
Total Responses & 212 & $111.1 \%{ }^{\mathrm{b}}$ \\
\hline $\begin{array}{l}{ }^{\mathrm{a}} \text { Percentages are based on } 191 \text { observations (respondents). } \\
\text { PPercentages sum to more than } 100 \text { because there were 212 responses from 191 respondents. }\end{array}$ \\
\hline \hline
\end{tabular}

Table 4. Perceived risks of agri-tourism participation, by producers, Miami-Dade County, FL (2001).

\begin{tabular}{|c|c|c|}
\hline \multirow[t]{2}{*}{ Type of Perceived Risk } & \multicolumn{2}{|c|}{ Responses } \\
\hline & Number & Percent $^{\mathrm{a}}$ \\
\hline Liability & 85 & $42.3 \%$ \\
\hline Added Costs or Reduced Productivity & 58 & $28.9 \%$ \\
\hline None & 57 & $28.4 \%$ \\
\hline Exposure to Insects and Disease & 7 & $3.5 \%$ \\
\hline Seasonality & 5 & $2.5 \%$ \\
\hline Other & 24 & $11.9 \%$ \\
\hline Total Responses & 236 & $117.5 \%{ }^{b}$ \\
\hline \multicolumn{3}{|c|}{$\begin{array}{l}{ }^{\mathrm{a}} \text { Percentages are based on } 204 \text { observations (respondents). } \\
\text { b Percentages sum to more than } 100 \text { because there were } 236 \text { responses from } 204 \text { respondents. }\end{array}$} \\
\hline
\end{tabular}

